Article

\title{
Deep Eutectic Solvent-Based Microextraction of Lead(II) Traces from Water and Aqueous Extracts before FAAS Measurements
}

\author{
Mohamed A. Habila 1,2,*(D), Najla AlMasoud ${ }^{3}\left(\mathbb{D}\right.$, Taghrid S. Alomar ${ }^{3, *}$, Zeid A. AlOthman ${ }^{1,2}$ (D), \\ Erkan Yilmaz $^{4,5}$ and Mustafa Soylak ${ }^{6}$
}

1 Advanced Materials Research Chair, Department of Chemistry, College of Science, King Saud University, P.O. Box 2455, Riyadh 11451, Saudi Arabia; zaothman@ksu.edu.sa

2 Department of Chemistry, College of Science, King Saud University, P.O. Box 2455,

Riyadh 11451, Saudi Arabia

3 Department of Chemistry, College of Science, Princess Nourah bint Abdulrahman University, Riyadh 11671, Saudi Arabia; nsalmasoud@pnu.edu.sa

4 Department of Analytical Chemistry, Faculty of Pharmacy, Erciyes University, 38039 Kayseri, Turkey; erkanyilmaz@erciyes.edu.tr

5 Nanotechnology Research and Application Center (ERNAM), Erciyes University, 38039 Kayseri, Turkey

6 Department of Chemistry, Faculty of Sciences, Erciyes University, 38039 Kayseri, Turkey; msoylak@gmail.com

* Correspondence: mhabila@ksu.edu.sa (M.A.H.); tsalomar@pnu.edu.sa (T.S.A.); Tel.: +96-614-674-198 (M.A.H.); +96-611-823-9548 (T.S.A.); Fax: +96-614-675-992 (M.A.H.)

Academic Editors: Magdalena Regel-Rosocka and Isabelle Billard check for Received: 22 July 2020; Accepted: 12 October 2020; Published: 19 October 2020

\begin{abstract}
Microextraction procedures for the separation of $\mathrm{Pb}$ (II) from water and food samples extracts were developed. A deep eutectic solvent composed of $\alpha$-benzoin oxime and iron(III) chloride dissolved in phenol was applied as a phase separator support. In addition, this deep eutectic mixture worked as an efficient extractor of $\mathrm{Pb}$ (II). The developed microextraction process showed a high ability to tolerate the common coexisting ions in the real samples. The optimum conditions for quantitative recoveries of $\mathrm{Pb}(\mathrm{II})$ from aqueous extracts were at $\mathrm{pH} 2.0$, conducted by adding $150 \mu \mathrm{L}$ from the deep eutectic solvent. The quantitative recoveries were obtained with various initial sample volumes up to $30 \mathrm{~mL}$. Limits of detection and limits of quantification of 0.008 and $0.025 \mu \mathrm{g} \mathrm{L}-1$ were achieved with a relative standard deviation (RSD\%) of 2.9 , which indicates the accuracy and sensitivity of the developed procedure. Recoveries from the reference materials, including TMDA 64.2, TMDA 53.3, and NCSDC-73349, were $100 \%, 97 \%$, and $102 \%$, respectively. Real samples, such as tap, lake, and river water, as well as food samples, including salted peanuts, chickpeas, roasted yellow corn, pistachios, and almonds, were successfully applied for $\mathrm{Pb}$ (II) analysis by atomic absorption spectroscopy (AAS) after applying the developed deep eutectic solvent-based microextraction procedures.
\end{abstract}

Keywords: deep eutectic solvent; microextraction; lead(II); water; atomic absorption spectroscopy

\section{Introduction}

Lead in the environment has increased due to urbanization and industrial development [1-3]. Lead may contaminate the environment via mining centers, dust movement, industrial byproducts, and exhaust from contaminated gasoline. In addition, accumulation and transference through the food chain leads to a more significant spread into soil, plants, water, and food, making its way into the human body $[4,5]$. Common pathways that lead to human exposure to lead include the respiratory system, where approximately $30-40 \%$ of the lead is transferred to the blood via 
absorption, which results in the circulation of the lead. The possibility of the circulating lead binding with erythrocytes is high, leading to its rapid distribution throughout the body, including in organs such as the liver and brain, and in the bones [6]. In addition, the presence of lead in the human body causes oxidative stress through reactive oxygen species production as well as reducing antioxidant defenses' ability such as by affecting superoxide dismutase and catalase enzymes [7-14]. Therefore, the accurate determination of lead is an important issue in analytical chemistry because of the very low concentrations in some samples as well as the presence of a matrix in real samples, which may interfere with instrumental determination [15-17]. However, the application of sample pretreatment, including preconcentration techniques such as solid-phase extraction [18-21], solid-phase microextraction [22,23], and dispersive liquid-liquid microextraction [16,24,25], has led to significant improvements in analytical methods and enabled the accurate determination of the targeted pollutants. The microextraction-based preconcentration process is more promising than traditional extraction processes such as solid-phase extraction or liquid-phase extraction [26,27]. Solid-phase microextraction and liquid-phase microextraction were recently introduced, and have many advantages, such as fast operation, as well as requiring a lower amount of chemicals during their conduction [28]. However, the liquid-phase microextraction process is superior to solid-phase microextraction due to its simple and quick phase separation as well as its ability to apply a direct injection of the separated phase for instrumental analysis $[27,29]$. The development of the microextraction steps to preconcentrate $\mathrm{Pb}$ (II) has been reported; for example, Zhou et al. [24] applied dithizone to chelate $\mathrm{Pb}$ (II) for dispersive liquid liquid microextraction (DLLME) application with a precision of $2.12 \%$ (RSD, $n=7$ ) and a detection limit of $0.95 \mathrm{ng} \mathrm{L}^{-1}$. Mandlate et al. [30] determined $\mathrm{Pb}$ (II) in soft drinks by applying dispersive liquid-liquid microextraction (DLLME) with GF-AAS and reported LODs of $0.072 \mathrm{ng} \mathrm{L}^{-1}$. Mohammedi et al. [31] applied a ligandless-based dispersive liquid-liquid microextraction process for $\mathrm{Pb}$ (II) microextraction from water for flame atomic absorption spectrometry determination. Faraji and Helalizadeh [16] determined $\mathrm{Pb}(\mathrm{II})$ in urine by applying DLLME before ultraviolet and visible spectrophotometry with a linear range from 0.01 to $100 \mu \mathrm{g} \mathrm{L}^{-1}$ and relative standard deviations of $15.3 \%$. Afzali et al. [32] developed displacement-dispersive liquid-liquid microextraction by solidification of floating organic drops for preconcentration and determination of $\mathrm{Pb}$ (II) by flame atomic absorption spectrometry with a linear range between 4 and $700 \mathrm{ng} \mathrm{mL}^{-1}$ with a detection limit of $0.7 \mathrm{ng} \mathrm{mL} \mathrm{m}^{-1}$. Shah et al. [33] developed an in-syringe system using ionic liquid for microextraction of $\mathrm{Pb}$ (II) with an LOD of $0.281 \mu \mathrm{g} \mathrm{L}-1$. Recently, a deep eutectic solvent was applied for microextraction as green solvents; it was composed of the coordination of hydrogen bond donors, such as long-chain carboxylic acids with hydrogen bond acceptors, such as quaternary ammonium salts or choline chloride, which reduce the melting point of the mixture, forming an organic viscus solution that is used to assess the separation of the aqueous and organic phases during microextraction procedures [34-38]. For example, Abolghasemi et al. [39] used microextraction procedures with a deep eutectic solvent for the preconcentration of pesticides from food. Sorouraddin et al. [40] applied the deep eutectic solvent for the development of reversed-phase-based microextraction for the separation of cadmium and zinc. Zounr et al. [41] extracted lead from water and food samples by applying deep eutectic and air-assisted liquid microextraction, and achieved LODs of $0.60 \mathrm{ng} \mathrm{L}^{-1}$. Alavi et al. [42] analyzed $\mathrm{Pb}$ (II) in blood samples using electrothermal atomic absorption spectroscopy (ETAAS), after applying deep eutectic microextraction procedures containing 1-octanol and $N, N, N$-cetyltrimethyl ammonium bromide as an extractor with a linear range between 1 and $200 \mathrm{ng} \mathrm{mL}^{-1}$. However, deep eutectic solvents have a broader composition, which may include metal chloride associations with electron donor molecular compounds; further investigations for microextraction application are required.

This work aimed to develop a microextraction process by applying a mixture of deep eutectic solvents, composed of $\alpha$-benzoin oxime and iron(III) chloride dissolved in phenol, for the attraction and separation of $\mathrm{Pb}(\mathrm{II})$ from aqueous samples. The parameters affecting the accuracy and sensitivity of the microextraction procedures were optimized, as well as the real samples' application, and the tolerance ability of foreign ions was investigated. 


\section{Results and Discussion}

\subsection{Investigations of the $p H$ of the Sample Solution on the Recovery of Pb(II)}

Deep eutectic solvents are promising for the attraction of heavy metals from aqueous solutions because they are entirely composed of nitrogen and oxygen in their structure, in addition to the main skeleton of organic derived materials including carbon and hydrogen [34,35]. The separation and extraction of heavy metal ions from a sample solution depends on the $\mathrm{pH}$ of the medium due to the complexation between metal ions and the ligand $[23,43]$. For this optimization, the $\mathrm{pH}$ was increased to 7 . The recovery was calculated and is presented in Figure 1. A strongly acidic medium of pH 2 showed the best recovery values, while weakly acidic mediums of pH 5 and 6 had lower recovery.

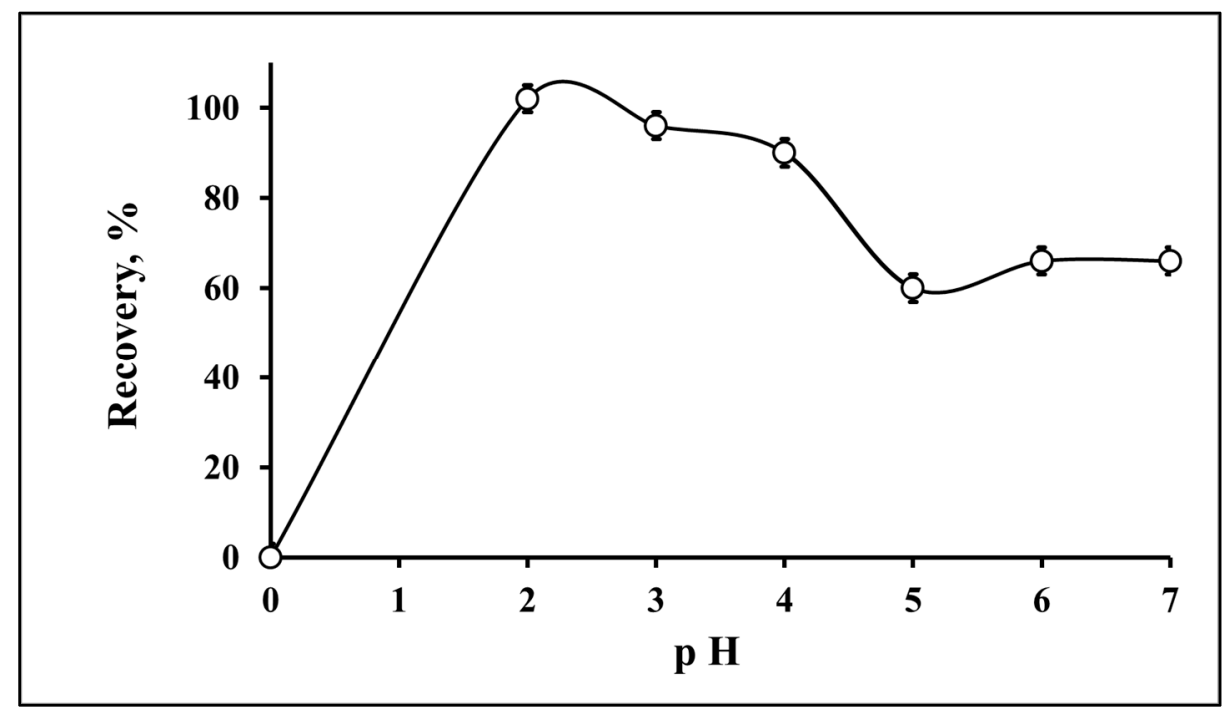

Figure 1. Evaluation of $\mathrm{pH}$ for the recovery of $\mathrm{Pb}(\mathrm{II})$ by DES-ME $(n=3)$.

\subsection{Optimization of the Deep Eutectic Solvent Quantity}

In the developed microextraction procedures, the deep eutectic mixture was formed by mixing the $\alpha$-benzoin oxime and iron(III) chloride dissolved in phenol, resulting in a sticky solution that could be uniformly distributed in the sample solution under vortex shaking conditions. This led to the formation of a homogenous cloudy solution; at this stage, $\mathrm{Pb}$ (II) was collected from the aqueous solution and attached to the deep eutectic organic phase due to the presence of $\alpha$-benzoin oxime. The advantage of the prepared deep eutectic solvent is the presence of the three components together, including phenol and iron(II) chloride, which are important for the deep eutectic solvent structure as well as the nitrogen atom and hydroxyl group in the structure of the $\alpha$-benzoin oxime ligand, which enhance the ability of the deep eutectic mixture to coordinate lead(II) from aqueous samples; this is a key point in the developed microextraction process. The role of phenol is to act as donor for the electrons (hydrogen bond donors (HBDs)) and the iron(III) chloride is to act as hydrogen-bond acceptors (HBAs)) during formation of the deep eutectic solvents. Phenol is reported for application as HBDs with choline chloride as HBAs [44]. The iron(III) chloride is reported as HBAs with thiomalic acid [45], ethylene glycol glycerol, malonic acid, pentaerythritol, xylitol, serine, alanine and glycine as HBDs [46]. In the present work, the combination between phenol and iron(III) chloride is applied for the first time based on our survey for preconcentration purposes. The deep eutectic solvents facilitate the phase separation during the microextraction process. The separation of the deep eutectic solvent phase by centrifugation led to an effective microextraction process. The volume of the deep eutectic mixture was a key parameter in achieving the quantitative recoveries. Therefore, it was investigated and is shown in Figure 2. The effect of changing the volume of the deep eutectic solvents was correlated to the microextraction efficiency in terms of recovery. The volume of deep eutectic solvent in the range 
of 50-100 $\mu \mathrm{L}$ exhibited a recovery of approximately $80 \%$, while the complete microextraction with the best recovery was approximately $100 \%$, which was achieved by injecting at least $150 \mu \mathrm{L}$ of the deep eutectic solution mixture.

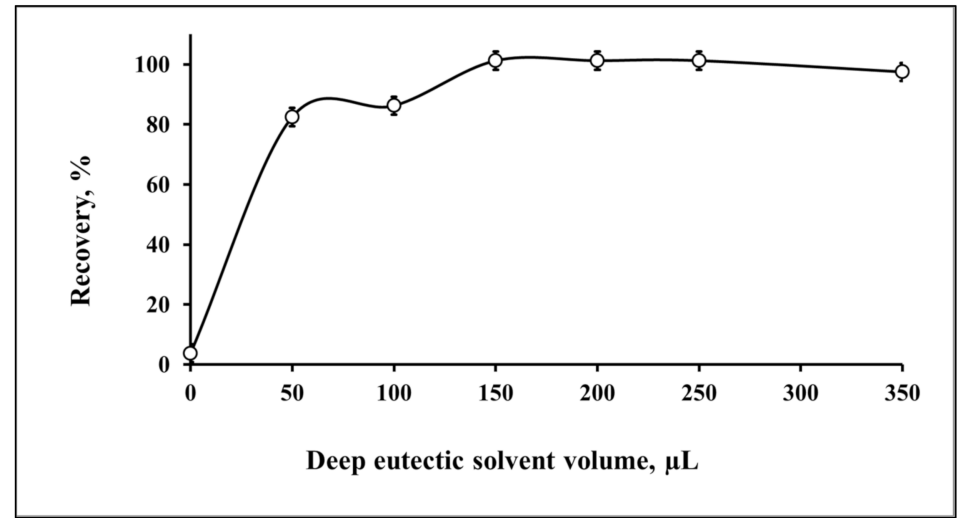

Figure 2. Optimization of the amount of the deep eutectic solvent for the recovery of $\mathrm{Pb}(\mathrm{II})$ by microextraction $(n=3)$.

\subsection{Tolerance of Foreign Ions in Relation to Recovery}

During real applications, the conditions of the microextraction media were affected by the presence of coexisting ions that may compete with the targeted analyte, leading to a reduction in the sensitivity of the method and a reduction in the recovery [47-50]. The coexisting ions, such as $\mathrm{F}^{-}, \mathrm{PO}_{4}{ }^{3-}, \mathrm{Ni}^{2+}, \mathrm{NO}_{3}{ }^{-}$, $\mathrm{Co}^{2+}, \mathrm{Zn}^{2+}, \mathrm{CO}_{3}{ }^{2-}, \mathrm{K}^{+} / \mathrm{Cl}^{-}, \mathrm{Mg}^{2+}, \mathrm{Ca}^{2+}, \mathrm{SO}_{4}{ }^{2-}$, and $\mathrm{Fe}^{2+}$, were investigated using the developed $\mathrm{DES}-\mathrm{ME}$ process for $\mathrm{Pb}(\mathrm{II})$ preconcentration to assess the selectivity and tolerance. The recoveries were in the range between $94 \%$ and $103 \%$ (Table 1), indicating that the developed DES-ME process for Pb(II) is matrix-independent.

Table 1. Recoveries of $\mathrm{Pb}(\mathrm{II})$ microextraction by deep eutectic solvent under various matrix applications $(n=3)$.

\begin{tabular}{cccc}
\hline Ions & Concentration $\left(\mathbf{m g ~ L}^{-\mathbf{1}}\right)$ & Salts & Recovery (\%) \\
\hline $\mathrm{F}^{-}$ & 800 & $\mathrm{NaF}$ & $100 \pm 1$ \\
$\mathrm{PO}_{4}{ }^{3-}$ & 500 & $\mathrm{Na}_{3} \mathrm{PO}_{4}$ & $95 \pm 2$ \\
$\mathrm{Ni}^{2+}$ & 5 & $\mathrm{Ni}$ & $100 \pm 2$ \\
$\mathrm{NO}_{3}{ }^{-}$ & 500 & $\left(\mathrm{NO}_{3}\right)_{2} \cdot 6 \mathrm{H}_{2} \mathrm{O}$ & $103 \pm 2$ \\
$\mathrm{Co}^{2+}$ & 10 & $\mathrm{NaNO}_{3}$ & $95 \pm 2$ \\
$\mathrm{Zn}^{2+}$ & 10 & $\mathrm{Co}\left(\mathrm{NO}_{3}\right)_{2}$ & $102 \pm 2$ \\
$\mathrm{CO}_{3}{ }^{2-}$ & 1200 & $\mathrm{Zn}\left(\mathrm{NO}_{3}\right)_{2}$ & $95 \pm 3$ \\
$\mathrm{~K}^{+} / \mathrm{Cl}^{-}$ & 5000 & $\mathrm{Na}_{2} \mathrm{CO}_{3}$ & $102 \pm 2$ \\
$\mathrm{Mg}^{2+}$ & 1500 & $\mathrm{KCl}^{2}$ & $98 \pm 4$ \\
$\mathrm{Ca}^{2+}$ & 800 & $\mathrm{Mg}\left(\mathrm{NO}_{3}\right)_{2} \cdot 6 \mathrm{H}_{2} \mathrm{O}$ & $103 \pm 2$ \\
$\mathrm{SO}_{4}{ }^{2-}$ & 400 & $\mathrm{CaCl}_{2}$ & $97 \pm 1$ \\
$\mathrm{Fe}^{2+}$ & 10 & $\mathrm{Na}_{2} \mathrm{SO}_{4}$ & $94 \pm 3$ \\
\hline
\end{tabular}

\subsection{Analytical Merit for the Developed DES-ME of Pb(II)}

The sample volume is an important factor for obtaining a high preconcentration factor [51-58]. The sample volume was studied in the range from 10 to $45 \mathrm{~mL}$ (Figure 3). The developed DES-ME of $\mathrm{Pb}$ (II) exhibited a high recovery up to $30 \mathrm{~mL}$. By considering the last extracted volume for the $\mathrm{Pb}$ (II) solution with an instrumental injection of $500 \mu \mathrm{L}$, the preconcentration factor was 60, as calculated via Equation (1):

$$
\text { Preconcentration Factor }=\frac{\text { Maximum Sample volume }(m L)}{\text { Last extracted volume }(m L)} .
$$




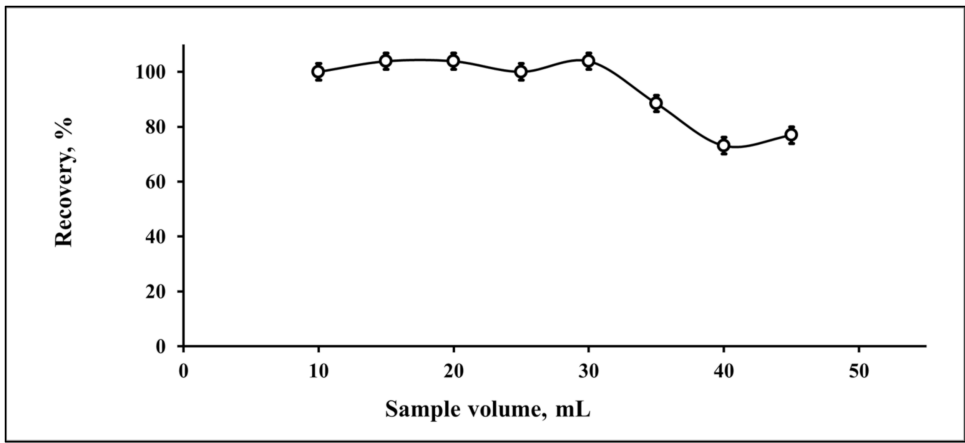

Figure 3. Evaluation of the sample volume for the deep eutectic-based microextraction of $\mathrm{Pb}(\mathrm{II})(n=3)$.

The developed DES-ME of $\mathrm{Pb}$ (II) exhibited limits of detection (LODs) and limits of quantification (LOQs) of 0.008 and $0.025 \mu \mathrm{g} \cdot \mathrm{L}^{-1}$, respectively, with an RSD\% of 2.9 , which indicates accuracy and sensitivity. In addition, the recoveries from the reference materials, including TMDA 64.2, TMDA 53.3, and NCSDC-73349, were 100\%, 97\%, and 102\%, respectively (Table 2).

Table 2. Validation of the DES-ME of $\mathrm{Pb}$ (II) from the certified reference material $(n=3)$.

\begin{tabular}{cccc}
\hline Reference Material & Certified Value in Last Phase & Found Value, $\mathbf{~ m g ~ L ~}^{\mathbf{- 1}}$ & Recovery (\%) $^{(\%)}$ \\
\hline TMDA 64.2 & 1.4 & $1.43 \pm 0.0$ & $100 \pm 0.0$ \\
TMDA 53.3 & 1.7 & $1.65 \pm 0.02$ & $97 \pm 1.2$ \\
NCSDC-73349 & 1.4 & $1.43 \pm 0.02$ & $102 \pm 1.4$ \\
\hline
\end{tabular}

\subsection{Real Food and Water Samples Analyses after Applying the Developed Deep Eutectic-Based Microextraction} of $\mathrm{Pb}(I I)$

Environmental monitoring for the determination of $\mathrm{Pb}(\mathrm{II})$ in daily consumed samples is recommended to ensure low levels of $\mathrm{Pb}$ (II) contamination and control the quality of food and water [47-53]. A group of real samples, including various food and water samples, were applied for the developed DES-ME of $\mathrm{Pb}$ (II) separation and preconcentration before atomic absorption spectroscopy AAS analysis. Table 3 presents the levels of detected $\mathrm{Pb}(\mathrm{II})$ in the analyzed samples. In view of the obtained results, it can be concluded that $\mathrm{Pb}$ (II) was detected only in trace amounts, which indicates a very low contamination level; in addition, it reveals the accuracy of the developed DES-ME of $\mathrm{Pb}$ (II), which was also applicable in the case of the samples with various matrices.

Table 3. Determination of $\mathrm{Pb}(\mathrm{II})$ in samples from water and food extracts $(n=3)$.

\begin{tabular}{|c|c|c|}
\hline \multicolumn{2}{|c|}{ Real Sample } & \multirow{2}{*}{$\begin{array}{c}\mathrm{Pb} \text { (II) Concentration Mean } \\
\pm \text { Standard Deviation }\end{array}$} \\
\hline & Tap water & \\
\hline Water samples $\left(\mathrm{mg} \mathrm{L}^{-1}\right)$ & Lake water & $0.15 \pm 0.02$ \\
\hline & River water & $0.13 \pm 0.01$ \\
\hline \multirow{5}{*}{ Food samples $\left(\mathrm{mg} \mathrm{kg}^{-1}\right)$} & Salted peanuts & $0.1 \pm 0.02$ \\
\hline & Chickpeas & BLD \\
\hline & Roasted yellow corn & $0.08 \pm 0.01$ \\
\hline & Pistachios & $\mathrm{BLD}^{*}$ \\
\hline & Almonds & $\mathrm{BLD}^{*}$ \\
\hline
\end{tabular}

* Below the limits of detection.

Furthermore, the addition/recovery experiments were conducted for the evaluation of the performance of the developed DES-ME of $\mathrm{Pb}$ (II) under various analyte concentration levels and in the presence of different real sample matrices. Table 4 presents the recovered $\mathrm{Pb}$ (II) concentrations with 
various spiking levels, which are in agreement with the added one, with recovery between $92 \%$ and $101 \%$.

Table 4. Addition/recovery of $\mathrm{Pb}(\mathrm{II})$ from water and food samples using the developed deep eutectic microextraction.

\begin{tabular}{|c|c|c|c|c|c|c|}
\hline \multirow{2}{*}{$\begin{array}{l}\text { Sample } \\
\text { Matric }\end{array}$} & \multicolumn{2}{|c|}{$\begin{array}{l}\text { Spiking Pb(II) } \\
0.5 \mathrm{mg} \mathrm{L}^{-1}\end{array}$} & \multicolumn{2}{|c|}{$\begin{array}{l}\text { Spiking } \mathrm{Pb}(\mathrm{II}) \\
1.0 \mathrm{mg} \mathrm{L}^{-1}\end{array}$} & \multicolumn{2}{|c|}{$\begin{array}{l}\text { Spiking Pb(II) } \\
2.0 \mathrm{mg} \mathrm{L}^{-1}\end{array}$} \\
\hline & $\begin{array}{c}\text { Detected } \\
\mathrm{Pb}(\mathrm{II}) \\
(\mathrm{mg} / \mathrm{L})\end{array}$ & Recovery & $\begin{array}{c}\text { Detected } \\
\mathrm{Pb}(\mathrm{II}) \\
(\mathrm{mg} / \mathrm{L})\end{array}$ & Recovery & $\begin{array}{c}\text { Detected } \\
\mathrm{Pb}(\mathrm{II}) \\
(\mathrm{mg} / \mathrm{L})\end{array}$ & Recovery \\
\hline Tap water & $0.48 \pm 0.10$ & 95 & $0.99 \pm 0.00$ & 99 & $1.95 \pm 0.30$ & 97 \\
\hline Chickpeas & $0.50 \pm 0.02$ & 100 & $1.01 \pm 0.10$ & 101 & $2.02 \pm 0.01$ & 101 \\
\hline Pistachios & $0.48 \pm 0.03$ & 95 & $0.92 \pm 0.01$ & 92 & $1.95 \pm 0.01$ & 97.4 \\
\hline
\end{tabular}

The efficiency of the developed $\mathrm{DES}-\mathrm{ME}$ of $\mathrm{Pb}(\mathrm{II})$ was compared with other microextraction methods from the literature $[21,23,24,30,33,34,42]$. The limits of detection of $0.008 \mu \mathrm{g} \mathrm{L} \mathrm{L}^{-1}$ for the developed DES-ME were between those of the other methods, as shown in Table 5.

Table 5. A comparison of the developed DES-ME of $\mathrm{Pb}(\mathrm{II})$ with microextraction methods from the literature.

\begin{tabular}{ccc}
\hline Extraction Procedures & LODs $\left(\boldsymbol{\mu g} \mathbf{~ L}^{-\mathbf{1}}\right)$ & Reference \\
\hline Solid-phase extraction & $0.1-2.8$ & {$[21]$} \\
$\mathrm{Fe}_{3} \mathrm{O}_{4}$ nanoparticles and ultrasound assisted dispersive liquid-liquid & 5.7 & {$[23]$} \\
Microextraction (NPU-DLLME) & 0.00095 & {$[24]$} \\
Dispersive liquid-liquid microextraction (DLLME) & 0.000072 & {$[30]$} \\
Dispersive liquid-liquid microextraction (DLLME) & 0.7 & {$[32]$} \\
Displacement-dispersive liquid-liquid microextraction by solidification & 0.281 & {$[33]$} \\
In-syringe system using ionic liquid for microextraction & 0.00060 & This study \\
Deep eutectic and air-assisted liquid microextraction & 0.008 & This \\
DES-ME & &
\end{tabular}

\section{Materials and Methods}

\subsection{Reagents and Chemicals}

Deionized water was used for the preparation and dilution of all solutions. The chemicals applied in this work were all of analytical grade. $\mathrm{A} \mathrm{Pb}(\mathrm{II})$ stock solution of $1000 \mathrm{mg} \mathrm{L}^{-1}$ was prepared from the nitrate salt and diluted daily for designed experiments. $\alpha$-Benzoin oxime, iron(III) chloride, phenol, sodium fluoride, sodium phosphate, nickel(II) nitrate, hexahydrate, sodium nitrate, lead(II) nitrate, cobalt(II) nitrate, zinc(II) nitrate, sodium carbonate, potassium chloride, magnesium nitrate hexahydrate, calcium chloride, sodium sulfate, and iron(II) nitrate were purchased from Sigma (St. Louis, MO, USA). Sodium hydroxide, hydrochloric acid, nitric acid, and hydrogen peroxide were purchased from Merck (Darmstadt, Germany).

\section{2. $\mathrm{DES}-\mathrm{ME}$ of $\mathrm{Pb}(\mathrm{II})$}

The deep eutectic extraction solution was obtained by mixing iron(III) chloride with phenol at a molar ratio of $1: 5$, warming the mixture at $50{ }^{\circ} \mathrm{C}$ for $10 \mathrm{~min}$, and stirring it for $60 \mathrm{~min}$ at room temperature. Afterwards, $0.01 \mathrm{~g}$ of $\alpha$-benzoin oxime was added to the mixture, which was stirred for an additional $60 \mathrm{~min}$ at room temperature, forming a homogenous sticky solution that was applied directly for the microextraction process. The melting point was measured by a Shimadzu (Kyoto, Japan) DSC-60 and found to be $28.6^{\circ} \mathrm{C}$. In addition, the viscosity of the DES mixture was measured by Viscolite 
700 and found to be $47 \mathrm{cps}$. The samples containing $\mathrm{Pb}(\mathrm{II})$ in a $50 \mathrm{~mL}$ tube were adjusted to $\mathrm{pH} 2 \mathrm{using}$ a Sartorius PT-10 pH meter (Sartorius, Gottingen, Germany). The pH was adjusted and stabilized using a phosphate buffer and controlled to the desired $\mathrm{pH}$ by adding drops of diluted hydrochloric acid $(0.01 \mathrm{M})$ or sodium hydroxide $(0.01 \mathrm{M})$. Then, a portion of the deep eutectic extraction solution (approximately $150 \mu \mathrm{L}$ ) was injected. The mixture was vortexed for $5 \mathrm{~min}$ to form a cloudy mixture. Centrifugation for $12 \mathrm{~min}$ at $4000 \mathrm{rpm}$ was applied for phase separation. The aqueous phase was discarded, and the remaining phase, including the $\mathrm{Pb}$ (II) analyte, was dissolved in nitric acid, to a final volume of $500 \mu \mathrm{L}$, which was detected by a flame atomic absorption spectrometer (Perkin Elmer model 3110, PerkinElmer, Inc., Shelton, CT, USA). The recovery was calculated by Equation (2):

$$
\text { Recovery } \%=\left(\frac{C_{f}}{C_{0}}\right) \times 100,
$$

where $C_{f}$ is the final concentration, and $C_{0}$ is the initial concentration.

The microextraction experiments were conducted in three replications. The Excel Microsoft Office program was used to calculate the average and standard deviation of $\mathrm{Pb}$ (II) concentration measurements for the replicates. The standard errors were calculated from the Equation (3):

$$
\text { Standard errors }(\mathrm{SE})=\frac{\text { Standard deviation }}{\sqrt{ } \mathrm{n}}
$$

where $\mathrm{n}$ is the number of replicates

\subsection{Validation and Real Applications}

Standard certified reference materials, including TMDA 64.2, TMDA 53.3, and NCSDC-73349, were applied for evaluating the performance and efficiency of the developed deep eutectic-based $\mathrm{Pb}(\mathrm{II})$ microextraction. In addition, tap, lake, and river water samples were filtered through a $0.45-\mu \mathrm{m}$ pore size filter, and then, $10 \mathrm{~mL}$ were applied for the developed deep eutectic-based $\mathrm{Pb}$ (II) microextraction following the above procedures. For food samples, including NCSDC-73349, salted peanuts, chickpeas, roasted yellow corn, pistachios, and almonds, $1.0 \mathrm{~g}$ was prepared, using nitric acid digestion to obtain a clear solution that was adjusted to $10 \mathrm{~mL}$ with deionized water. Two milliliters of the food sample extract were applied to the developed deep eutectic-based $\mathrm{Pb}$ (II) microextraction. A spiking of a certain amount of $\mathrm{Pb}(\mathrm{II})$ and the recovery from tap water, chickpeas, and pistachios was investigated using $\mathrm{Pb}$ (II) concentrations of $0.5,1.0$, and $2.0 \mathrm{mg} \mathrm{L}^{-1}$.

\section{Conclusions}

The deep eutectic solvent mixture composed of $\alpha$-benzoin oxime and iron(III) chloride dissolved in phenol showed a high efficiency for interaction and association with $\mathrm{Pb}$ (II) during the microextraction process. In addition, the deep eutectic mixture played an important role in the phase separation, leading to an efficient and selective preconcentration with high recovery from aqueous solutions. The relative standard deviation of 2.9 reveals the stability of the results and indicates the suitability of the developed deep eutectic microextraction for real applications. The addition/recovery analysis showed close agreement between the spiked and detected concentrations, with recoveries between $92 \%$ and $106 \%$. The developed DES-ME of $\mathrm{Pb}$ (II) exhibited high tolerance for various ions, including $\mathrm{F}^{-}$, $\mathrm{PO}_{4}{ }^{3-}, \mathrm{Ni}^{2+}, \mathrm{NO}_{3}{ }^{-}, \mathrm{Co}^{2+}, \mathrm{Zn}^{2+}, \mathrm{CO}_{3}{ }^{2-}, \mathrm{K}^{+} / \mathrm{Cl}^{-}, \mathrm{Mg}^{2+}, \mathrm{Ca}^{2+}, \mathrm{SO}_{4}{ }^{2-}$, and $\mathrm{Fe}^{2+}$.

Author Contributions: Conceptualization, M.A.H. and M.S.; Funding acquisition, N.A., T.S.A., and Z.A.A.; Investigation, M.A.H., T.S.A., Z.A.A., and M.S.; Methodology, M.A.H. and E.Y.; Resources, Z.A.A.; Supervision, M.S.; Validation, M.S.; Writing-original draft, M.A.H. and N.A.; Writing—review and editing, M.A.H., Z.A.A., E.Y., and M.S. All authors have read and agreed to the published version of the manuscript.

Funding: This work was funded by the Deanship of Scientific Research at Princess Nourah Bint Abdulrahman University (grant number RGP-1440-0023). 
Acknowledgments: The authors acknowledge the Deanship of Scientific Research at Princess Nourah Bint Abdulrahman University.

Conflicts of Interest: The authors declare no conflict of interest.

\section{References}

1. Balkhair, K.S.; Ashraf, M.A. Field accumulation risks of heavy metals in soil and vegetable crop irrigated with sewage water in western region of Saudi Arabia. Saudi J. Biol. Sci. 2016, 23, S32-S44. [CrossRef]

2. Vardhan, K.H.; Kumar, P.S.; Panda, R.C. A review on heavy metal pollution, toxicity and remedial measures: Current trends and future perspectives. J. Mol. Liq. 2019, 290, 111197. [CrossRef]

3. Masindi, V.; Muedi, K.L. Environmental Contamination by Heavy Metals. In Heavy Metals; InTech: London, UK, 2018.

4. Chandra, R.; Bharagava, R.N.; Yadav, S.; Mohan, D. Accumulation and distribution of toxic metals in wheat (Triticum aestivum L.) and Indian mustard (Brassica campestris L.) irrigated with distillery and tannery effluents. J. Hazard. Mater. 2009, 162, 1514-1521. [CrossRef] [PubMed]

5. ALOthman, Z.A.; Habila, M.A.; Al-Shalan, N.H.; Alfadul, S.M.; Ali, R.; Rashed, I.G.A.A.; Alfarhan, B. Adsorptive removal of $\mathrm{Cu}(\mathrm{II})$ and $\mathrm{Pb}(\mathrm{II})$ onto mixed-waste activated carbon: Kinetic, thermodynamic, and competitive studies and application to real wastewater samples. Arab. J. Geosci. 2016, 9, 315-323. [CrossRef]

6. Wani, A.L.; Ara, A.; Usmani, J.A. Lead toxicity: A review. Interdiscip. Toxicol. 2015, 8, 55-64. [CrossRef]

7. Al-Othman, A.M.; Al-Othman, Z.A.; El-Desoky, G.E.; Aboul-Soud, M.A.M.; Habila, M.A.; Giesy, J.P. Erratum to: Lead in drinking water and human blood in Riyadh City, Saudi Arabia. Arab. J. Geosci. 2013, 6, 4091. [CrossRef]

8. Liu, J.; Gao, D.; Chen, Y.; Jing, J.; Hu, Q.; Chen, Y. Lead exposure at each stage of pregnancy and neurobehavioral development of neonates. Neurotoxicology 2014, 44, 1-7. [CrossRef]

9. El-Desoky, G.E.; Aboul-Soud, M.A.M.; Al-Othman, Z.A.; Habila, M.; Giesy, J.P. Seasonal concentrations of lead in outdoor and indoor dust and blood of children in Riyadh, Saudi Arabia. Environ. Geochem. Health 2014, 36, 583-593. [CrossRef]

10. Safety and Health Topics |Lead-Health Effects| Occupational Safety and Health Administration. Available online: https://www.osha.gov/SLTC/lead/healtheffects.html (accessed on 28 September 2019).

11. The Health Effects of Environmental Lead Exposure: Closing Pandora's Box-Behavioral Measures of Neurotoxicity-NCBI Bookshelf. Available online: https://www.ncbi.nlm.nih.gov/books/NBK234984/ (accessed on 19 December 2019).

12. The Environmental Case Management of Lead-exposed Persons Guidelines for Public Health Units; Ministry of Health: Wellington, New Zealand, 2012; ISBN 9780478373950.

13. Rosin, A. The long-term consequences of exposure to lead. Isr. Med. Assoc. J. 2009, 11, 689-694.

14. Dobrakowski, M.; Boroń, M.; Birkner, E.; Kasperczyk, A.; Chwalińska, E.; Lisowska, G.; Kasperczyk, S. The Effect of a Short-Term Exposure to Lead on the Levels of Essential Metal Ions, Selected Proteins Related to Them, and Oxidative Stress Parameters in Humans. Oxid. Med. Cell. Longev. 2017, 2017, 8763793. [CrossRef]

15. AlOthman, Z.A.; Habila, M.A.; Yilmaz, E.; Warad, I.; Soylak, M. Lead Preconcentration as RAC-(E, E)-N,N'-bis(2-Chlorobenzylidene)Cyclohexane-1,2-Diamine Complexes from Water and Tobacco Samples by Dispersive Liquid-Liquid Microextraction. J. Anal. Chem. 2015, 70, 608-612. [CrossRef]

16. Faraji, H.; Helalizadeh, M. Lead Quantification in Urine Samples of Athletes by Coupling DLLME with UV-Vis Spectrophotometry. Biol. Trace Elem. Res. 2017, 176, 258-269. [CrossRef] [PubMed]

17. López-García, I.; Vicente-Martínez, Y.; Hernández-Córdoba, M. Determination of cadmium and lead in edible oils by electrothermal atomic absorption spectrometry after reverse dispersive liquid-liquid microextraction. Talanta 2014, 124, 106-110. [CrossRef] [PubMed]

18. ALOthman, Z.A.; Habila, M.; Yilmaz, E.; Soylak, M. Solid phase extraction of Cd(II), Pb(II), Zn(II) and Ni(II) from food samples using multiwalled carbon nanotubes impregnated with 4-(2-thiazolylazo)resorcinol. Microchim. Acta 2012, 177, 397-403. [CrossRef]

19. Habila, M.A.; ALOthman, Z.A.; El-Toni, A.M.; Soylak, M. Combination of Syringe-Solid Phase Extraction with Inductively Coupled Plasma Mass Spectrometry for Efficient Heavy Metals Detection. Clean (Weinh) 2016, 44, 720-727. [CrossRef] 
20. Habila, M.A.; AlOthman, Z.A.; Yilmaz, E.; Soylak, M. Activated carbon cloth filled pipette tip for solid phase extraction of nickel(II), lead(II), cadmium(II), copper(II) and cobalt(II) as 1,3,4-thiadiazole-2,5-dithiol chelates for ultra-trace detection by FAAS. Int. J. Environ. Anal. Chem. 2018, 98, 171-181. [CrossRef]

21. AlOthman, Z.A.; Yilmaz, E.; Habila, M.; Soylak, M. Solid phase extraction of metal ions in environmental samples on 1-(2-pyridylazo)-2-naphthol impregnated activated carbon cloth. Ecotoxicol. Environ. Saf. 2015, 112, 74-79. [CrossRef]

22. Habila, M.A.; ALOthman, Z.A.; El-Toni, A.M.; Labis, J.P.; Li, X.; Zhang, F.; Soylak, M. Mercaptobenzothiazole-functionalized magnetic carbon nanospheres of type Fe3O4@SiO2@C for the preconcentration of nickel, copper and lead prior to their determination by ICP-MS. Microchim. Acta 2016, 2377-2384. [CrossRef]

23. Habila, M.A.; AlOthman, Z.A.; Soylak, M. Fe3O4nanoparticles and ultrasound assisted dispersive liquid-liquid microextraction of lead(ii) for its microsampling flame atomic absorption spectrometric determination in food and environmental samples. RSC Adv. 2014, 4, 55610-55614. [CrossRef]

24. Zhou, Q.; Zhao, N.; Xie, G. Determination of lead in environmental waters with dispersive liquid-liquid microextraction prior to atomic fluorescence spectrometry. J. Hazard. Mater. 2011, 189, 48-53. [CrossRef]

25. Reverse dispersive liquid-liquid microextraction for the isolation of $\mathrm{Cd}$ and $\mathrm{Pb}$ from edible oils. Available online: https://microextraction.blogspot.com/2014/05/reverse-dispersive-liquid-liquid.html (accessed on 19 December 2019).

26. Jalili, V.; Barkhordari, A.; Norouzian Baghani, A. The role of microextraction techniques in occupational exposure assessment. A review. Microchem. J. 2019, 150, 104086. [CrossRef]

27. Yamini, Y.; Rezazadeh, M.; Seidi, S. Liquid-phase microextraction-The different principles and configurations. Trends Analyt Chem. 2019, 112, 264-272. [CrossRef]

28. Saqaf Jagirani, M.; Soylak, M. A Review: Recent Advances in Solid Phase Microextraction of Toxic Pollutants Using Nanotechnology Scenario. Microchem. J. 2020, 159, 105436-105453. [CrossRef]

29. Rutkowska, M.; Płotka-Wasylka, J.; Sajid, M.; Andruch, V. Liquid-phase microextraction: A review of reviews. Microchem. J. 2019, 149, 103989. [CrossRef]

30. Mandlate, J.S.; Soares, B.M.; Seeger, T.S.; Vecchia, P.D.; Mello, P.A.; Flores, E.M.M.; Duarte, F.A. Determination of cadmium and lead at sub-ppt level in soft drinks: An efficient combination between dispersive liquid-liquid microextraction and graphite furnace atomic absorption spectrometry. Food Chem. 2017, 221, 907-912. [CrossRef]

31. Mohammadi, S.Z.; Shamspur, T.; Baghelani, Y.M. Combination of flame atomic absorption spectrometry with ligandless-dispersive liquid-liquid microextraction for preconcentration and determination of trace amount of lead in water samples. Bull. Chem. Soc. Ethiop. 2013, 27, 161-168. [CrossRef]

32. Afzali, D.; Fayazi, M.; Mostafavi, A. Displacement-dispersive liquid-liquid microextraction based on solidification floating organic drop trace amounts of lead in water sample prior to flame atomic absorption spectrometry determination. J. Chil. Chem. Soc. 2013, 58, 1593-1596. [CrossRef]

33. Shah, F.; Soylak, M.; Kazi, T.G.; Afridi, H.I. Single step in-syringe system for ionic liquid based liquid microextraction combined with flame atomic absorption spectrometry for lead determination. J. Anal. At. Spectrom. 2012, 27, 1960-1965. [CrossRef]

34. Smith, E.L.; Abbott, A.P.; Ryder, K.S. Deep Eutectic Solvents (DESs) and Their Applications. Chem. Rev. 2014, 114, 11060-11082. [CrossRef]

35. Kalhor, P.; Ghandi, K. Deep eutectic solvents for pretreatment, extraction, and catalysis of biomass and food waste. Molecules 2019, 24, 4012. [CrossRef]

36. Makoś, P.; Słupek, E.; Gębicki, J. Hydrophobic deep eutectic solvents in microextraction techniques-A review. Microchem. J. 2020, 152, 104384.

37. Mogaddam, M.R.A.; Nemati, M.; Farajzadeh, M.A.; Lotfipour, F.; Nabil, A.A.A.; Mohebbi, A.; Ghorbanpour, H. Application of natural deep eutectic solvents-based in-syringe dispersive liquid-liquid microextraction for the extraction of five acaricides in egg samples. Int. J. Environ. Anal. Chem. 2020, 1-16. [CrossRef]

38. Yousefi, S.M.; Shemirani, F.; Ghorbanian, S.A. Hydrophobic Deep Eutectic Solvents in Developing Microextraction Methods Based on Solidification of Floating Drop: Application to the Trace HPLC/FLD Determination of PAHs. Chromatographia 2018, 81, 1201-1211. [CrossRef] 
39. Abolghasemi, M.M.; Piryaei, M.; Imani, R.M. Deep eutectic solvents as extraction phase in head-space single-drop microextraction for determination of pesticides in fruit juice and vegetable samples. Microchem. J. 2020, 158, 105041. [CrossRef]

40. Sorouraddin, S.M.; Farajzadeh, M.A.; Okhravi, T. Application of deep eutectic solvent as a disperser in reversed-phase dispersive liquid-liquid microextraction for the extraction of $\mathrm{Cd}(\mathrm{II})$ and $\mathrm{Zn}$ (II) ions from oil samples. J. Food Compos. Anal. 2020, 93, 103590. [CrossRef]

41. Zounr, R.A.; Tuzen, M.; Khuhawar, M.Y. A simple and green deep eutectic solvent based air assisted liquid phase microextraction for separation, preconcentration and determination of lead in water and food samples by graphite furnace atomic absorption spectrometry. J. Mol. Liq. 2018, 259, 220-226. [CrossRef]

42. Alavi, L.; Seidi, S.; Jabbari, A.; Baheri, T. Deep eutectic liquid organic salt as a new solvent for carrier-mediated hollow fiber liquid phase microextraction of lead from whole blood followed by electrothermal atomic absorption spectrometry. New J. Chem. 2017, 41, 7038-7044. [CrossRef]

43. AlOthman, Z.A.; Al-Shaalan, N.H.; Habila, M.A.; Unsal, Y.E.; Tuzen, M.; Soylak, M. Dispersive liquid-liquid microextraction of lead(II) as 5-(4-dimethylaminobenzylidene) rhodanine chelates from food and water samples. Environ. Monit. Asses. 2015, 187, 9-17. [CrossRef]

44. Zhong, F.Y.; Peng, H.L.; Tao, D.J.; Wu, P.K.; Fan, J.P.; Huang, K. Phenol-Based Ternary Deep Eutectic Solvents for Highly Efficient and Reversible Absorption of NH3. ACS Sustain. Chem. Eng. 2019, 7, 3258-3266. [CrossRef]

45. Habila, M.A.; Alabdullkarem, E.A.; ALOthman, Z.A.; Yilmaz, E.; Soylak, M. Thiomalic acid/ferric chloride-based deep eutectic solvent for microextraction of chromium in natural water samples prior to FAAS analysis. Int. J. Environ. Anal. Chem. 2020, 1-9. [CrossRef]

46. Liu, F.; Xue, Z.; Zhao, X.; Mou, H.; He, J.; Mu, T. Catalytic deep eutectic solvents for highly efficient conversion of cellulose to gluconic acid with gluconic acid self-precipitation separation. Chem. Commun. 2018, 54, 6140-6143. [CrossRef] [PubMed]

47. Zheng, C.; Hu, L.; Hou, X.; He, B.; Jiang, G. Headspace Solid-Phase Microextraction Coupled to Miniaturized Microplasma Optical Emission Spectrometry for Detection of Mercury and Lead. Anal. Chem. 2018, 90, 3683-3691. [CrossRef] [PubMed]

48. Naeemullah, N.; Shah, F.; Kazi, T.G.; Afridi, H.I.; Khan, A.R.; Arain, S.S.; Arain, M.S.; Panhwar, A.H. Switchable dispersive liquid-liquid microextraction for lead enrichment: A green alternative to classical extraction techniques. Anal. Methods 2016, 8, 904-911. [CrossRef]

49. Habila, M.A.; AlOthman, Z.A.; El-Toni, A.M.; Al-Tamrah, S.A.; Soylak, M.; Labis, J.P. Carbon-coated $\mathrm{Fe}_{3} \mathrm{O}_{4}$ nanoparticles with surface amido groups for magnetic solid phase extraction of $\mathrm{Cr}$ (III), $\mathrm{Co}$ (II), $\mathrm{Cd}$ (II), $\mathrm{Zn}$ (II) and $\mathrm{Pb}(\mathrm{II})$ prior to their quantitation by ICP-MS. Microchim. Acta 2017, 184, 2645-2651. [CrossRef]

50. AlOthman, Z.A.; Habila, M.A.; Yilmaz, E.; Al-Harbi, N.M.; Soylak, M. Supramolecular microextraction of cobalt from water samples before its microsampling flame atomic absorption spectrometric detection. Int. J. Environ. Anal. Chem. 2015, 95, 1311-1320. [CrossRef]

51. Tuzen, M.; Soylak, M.; Citak, D.; Ferreira, H.S.; Korn, M.G.A.; Bezerra, M.A. A preconcentration system for determination of copper and nickel in water and food samples employing flame atomic absorption spectrometry. J. Hazard. Mater. 2009, 162, 1041-1045. [CrossRef]

52. Koosha, E.; Shamsipur, M.; Salimi, F.; Ramezani, M. A microextraction method based on precipitation for the simultaneous separation and preconcentration of cadmium and lead before their determination by FAAS: Experimental design methodology. Sep. Sci. Technol. 2020, 1-9. [CrossRef]

53. Soylak, M.; Elci, L.; Dogan, M. Determination of trace amounts of cobalt in natural water samples as 4-(2-Thiazolylazo) recorcinol complex after adsorptive preconcentration. Anal. Lett. 1997, 30, 623-631. [CrossRef]

54. Movahhedi, F.; Maghsodi, A.; Adlnasab, L. Response surface methodology for heavy metals removal by tioglycolic-modified $\mathrm{Zn}-\mathrm{Fe}$ layer double hydroxide as a magnetic recyclable adsorbent. Chem. Pap. 2020, 74, 3169-3182. [CrossRef]

55. Tuzen, M.; Soylak, M.; Elci, L.; Dogan, M. Column solid phase extraction of copper, iron, and zinc ions at trace levels in environmental samples on amberlite XAD-7 for their flame atomic absorption spectrometric determinations. Anal. Lett. 2004, 37, 1185-1201. [CrossRef]

56. Sadeghi, M.; Rostami, E.; Kordestani, D.; Veisi, H.; Shamsipur, M. Simultaneous determination of ultra-low traces of lead and cadmium in food and environmental samples using dispersive solid-phase extraction 
(DSPE) combined with ultrasound-assisted emulsification microextraction based on the solidification of floating organic drop (UAEME-SFO) followed by GFAAS. RSC Adv. 2017, 7, 27656-27667.

57. Rivas, R.E.; López-García, I.; Hernández-Córdoba, M. Determination of traces of lead and cadmium using dispersive liquid-liquid microextraction followed by electrothermal atomic absorption spectrometry. Microchim. Acta 2009, 166, 355-361. [CrossRef]

58. Górecki, T.; Pawliszyn, J. Determination of Tetraethyllead and Inorganic Lead in Water by Solid Phase Microextraction/Gas Chromatography. Anal. Chem. 1996, 68, 3008-3014. [CrossRef]

Sample Availability: Samples of the compounds, including the DES mixture, are available from the authors.

Publisher's Note: MDPI stays neutral with regard to jurisdictional claims in published maps and institutional affiliations.

(C) 2020 by the authors. Licensee MDPI, Basel, Switzerland. This article is an open access article distributed under the terms and conditions of the Creative Commons Attribution (CC BY) license (http://creativecommons.org/licenses/by/4.0/). 